\title{
A Report on the History of the Acheulean Industry of Mai Idon Toro in the Central-Region of Nigeria
}

\author{
Jock Matthew Agai ${ }^{1}$ \\ ${ }^{1}$ School of Religion, Philosophy and Classics, University of KwaZulu-Natal, South Africa \\ Correspondence: Jock M. Agai, School of Religion, Philosophy and Classics, University of KwaZulu-Natal, South \\ Africa. Tel: 234-9043-686-988. E-mail: leadershipserve@yahoo.ca, agaijock@yahoo.ca
}

Received: April 12, 2021; Accepted: May 19, 2021; Published: May 19, 2021

Funding Information: The School of Religion, Philosophy and Classics, University of KwaZulu-Natal sponsored the fieldwork in NAFOK likewise other activities that led to the successful completion of this research.

\begin{abstract}
The last time the Acheulean tools at Mai Idon Toro (NAFOK) were collected and studied scientifically by different archaeologists/historians for the purpose of national and international patronage was in the 1920s through the 1960s. After the 60s up-to-date, many writers have been writing about the Acheulean tools in NAFOK without having a physical contact with the tools or without having a direct understanding of the dilapidated state of the Acheulean site in NAFOK. More so, in the process of this study, I have not come across any single library material that deals specifically and wholly with the Acheulean industry in NAFOK, instead; the subject is casually or indirectly referenced as secondary. The information from the secondary sources I collected about NAFOK was peripheral and in distinct pieces seemingly because a specific author had not wholly dealt with the subject. This instigated the need to visit the Acheulean site in NAFOK in search of primary sources or information. This research is a study of the history of the researches done strictly about NAFOK and its Acheulean finds. The aims of this research are first, to give an update on the history of researches done about the Acheulean in NAFOK and second, to create further awareness on the need to encourage the patronage of public archaeology among Nigerians using the Acheulean site in NAFOK as a case study.

Intradisciplinary and/or interdisciplinary implications: The presence of fossils and bones of early humans found in Eastern, Northern and Southern Africa are often referred to as the "direct evidence" for the existence of early humans in these regions of Africa. This is so because there is a view among many archaeologists, anthropologists and paleontologists according to which bones are reliable evidence for the existence of early humans than stone tools. Bone tools or bone evidence for the existence of early humans in West Africa is scanty. Archaeologists rely on stone tools to explain the probable existence of early humans in West Africa and the stone tools are referred to as "indirect evidence." It is likely that early humans might have lived in NAFOK not because direct evidence has been found but indirect evidence. This research is a study of the indirect evidence found in NAFOK for the existence of early humans. Historical archeologists and students of anthropology and West African history would find this research of great benefit because it discusses the contentious history of the view according to which early humans lived in NAFOK millions of years ago.
\end{abstract}

Keywords: acheul, early humans, evolution, Mai Idon Toro, modern humans, NAFOK, Oldowan

\section{Introduction}

There are many reasons why archaeology and paleontology in West Africa is not highly patronized by both local and international scholars in a similar way it is patronized in the Eastern, Southern and Northern Africa (Boateng, 1978, p.102; Lange, 2004, p.319). The stereotypic assumption according to which West Africa did not contribute to human civilization derailed the influence of public archaeology among its citizens. In most cases, the origin of human civilization among West Africans had been attributed to the Semitic Peoples or the Egyptians or the Ethiopians or the Greco-Roman People or the Europeans or the Asians or the Americans. This could be one of the reasons why some major ethnic groups in West Africa and especially in Nigeria believed that they originated from some foreign ancient civilized countries. The Yorubas for example believed they originated from Arabia or Egypt or Israel while the Hausas say they came from Mesopotamia and the Igbo's have a view according to which they originated from Israel (Shaw, 1978, p.12; cf. Agai, 2014, pp.3-4). 
The low interest or the non-preservation and conservation of heritage sites or monuments in Nigeria are other reasons why public archeology is poorly patronized. There is also a lack of funding and institutional support by the Nigerian government to promote the study and patronization of public archeology (Wesler, 2002, p.25). Students of both tertiary and primary institutions hardly patronize heritage sites within Nigeria. Most vacations or holidays by public servants and politicians are mostly done in foreign countries without a consideration of relevant historical or heritage sites within Nigeria or West Africa for patronage. There is also inadequate or a lack of professional archeologists in Nigeria and especially in Northern Nigeria who are to undertake professional excavations and scientific study of artefacts. This could be why most archeological finds in Nigeria were mostly conducted by the Europeans from the 1920sto the 1960s (cf. Shaw, 1978, p.12).

In the twenty-first century, there seemed to be a slight improvement also in the study of archeology amongst some Nigerians and this is so because some institutions are beginning to introduce archeology as a field of study or career. The University of Jos in Plateau State where NAFOK is located introduced archeology as a field of study in 2013 and have since graduated its first set of degree students. The authorities in the Department of Archeology and Heritage Studies of the University of Jos deserve some commendation for their contribution to the study of archeology and heritage likewise the management of the Institute of Archaeology and Museum Studies in Jos are also promoting the study of archaeology among West Africans.

At the moment, it is difficult to find Acheulean tools or tools that reached millions of years made up of wood and bones in Jos Plateau except stone tools. This is so because the varying temperatures and soil condition in Nigeria and on the Jos Plateau in particular militates the survival of woods or bone artefacts that reached millions of years (Shaw, 2004, p. 25). This is why this research is centered on the reports about the study of Stone Age tools. In this research, I gave an update regarding the history of the study of the stone tools found in NAFOK.

I explained the history of the Acheulean from a general perspective and narrowed it to the Acheulean in NAFOK. The aim of this research is achieved methodologically through a historical study of the writings of previous authors or archeologists that worked on the Acheulean culture found in NAFOK. The hypothesis for this research is developed based on the findings and conclusions of previous writers on the subject and also based on a physical study of the Stone Age artefacts found in NAFOK in 2020 by a group of researchers led by Dr. Agai Jock Matthew.

The National Commission for Museums and Monuments in Nigeria, comprising of a body of professionals in the study of antiquity designated and recommended that NAFOK be declared a National Monument. The Director General of the Commission submitted a letter of intention to the Federal Government to implement the official recognition of NAFOK as a National Monument on $15^{\text {th }}$ November, 2013 (see Appendix A). Instead, the Acheulean site in NAFOK is left open, unguided, uncontrolled and allowed for grazing of animals and for subsistence farming by the locals. The site is so unguided to the point that any individual from anywhere can go into the site and take whatever item or artifact he or she finds. The declaration of intention and recommendation made by the National Commission for Museum Studies to the Plateau State and the Federal Government of Nigeria to recognize NAFOK as a National Monument suggests that they have accepted the works of the 1920s-onward archeologists and historians that proposed that the Acheulean industry existed in NAFOK.

\section{A Socio- Historical Nomenclature of Mai Idon Toro (NAFOK)}

The current residences and the entire people of Mai Idon Toro believed that the name "Mai Idon Taro" was a nickname or slogan used by some Hausa traders and other miners that resided at the location during the Plateau mining boost which took place from the late eighteenth to the early and the middle twentieth century's. The indigenes of Mai Idon Toro said that that there was a white man who was a British explorer that served as a foreman in-charge of tin mining covering the entire Mai Idon Toro location. The white man is monophthalmic, meaning; he had one eye for view because the other eye is visually impaired. The laborers most of whom were the local indigenes of Mai Idon Toro comprising mostly of the Berom people and other migrants that came from other parts of Nigeria especially the northerners addressed or described the foreman as Mai Idon Toro which are Hausa (a lingua franca used in the central region of Nigeria) words that is phrased in English "the Man with the Eye of a Coin."They compared the visual impairment of the white man's eye to the Nigerian coin that was round and goldlike in color thus the name Mai Idon Toro that also means the man with a gold colored eye that looked like a coin. (Note 1)

The twenty-first century residences of Mai Idon Toro claimed that, before mining activities begun in the late eighteenth century, the original name of Mai Idon Toro was NAFOK. (Note 2) Most writers that have written about NAFOK in the past used the name Mai Idon Toro but in this research, I shall honor the people by using the term NAFOK because they advised me to so. In cases where previous authors used the name Mai Idon Toro, I shall bracket it with the name NAFOK. NAFOK is one of the major economic centers in Foron, Barkin Ladi 
Government Council of Plateau state, Nigeria. The geographical coordinates of NAFOK in decimal degrees (WGS84) reads Latitude 9.717 and longitude 8.983 while the geographical coordinates of the same area in minutes seconds (WGS84) reads Latitude $943^{\prime} 00$ " and Longitude 8 59' 00."(Note 3)

The people of NAFOK are over 40, 000. They are Berom by tribe. The few Hausa-Fulani that resided in the area left in 2001 after the ethno-religious conflicts that arose in Jos-Plateau. The community solely depends on farming of crops such as maize, millet, potato, sugarcane and a variety of vegetables often sold to other states of Nigeria. They also breed many domestic animals like goats, cows, chickens and many more. There are many schools and a hospital in the community together with a functional newly built community library. The people of NAFOK are business-minded, accommodative and friendly and are united among themselves. The site archaeologists are interested in NAFOK, has been ravaged by repeated mining activities thus creating valleys and contours rehashing the landscape of the area to the point that farming on the site activities are limited as well.

\section{The Acheulean Industry}

\subsection{Before the Acheulean}

The progressive origins of human development had passed through various stages, starting from the first or the earliest life on earth unto the emergence of modern humans. The biological theory of human evolution is a view according to which the first life on earth emerged from non-living matter in the aquatic environments from where it developed and formed minute microscopic organisms, and afterward the minute organisms grew and became macroscopic. The macroscopic organisms through a process of time developed into some fish-like creatures and to some terrestrial- arboreal beings and terrestrial/dry land ape-like creatures which gradually developed in millions of years into early and finally to modern humans (Welch 1963:87-88). On the evolution of humans in particular starting from the ape-like creatures, Gore explained that the evolutionary stages started in the following progressive order: tarsiers - Esomias - New World Monkeys - Old World Monkeys - gibbons - orangutans gorillas - chimpanzees - early humans and finally modern humans (Gore, 2003, p.37).

The production of tools and the spectacular use of the tools were initiated primarily due to brain function and brain development starting from some of the stages of the early human civilization popularly referred to as the Oldowan through the Acheulean Industries. Before the Acheulean, early humans created tools made-up of bones, woods and stones. The Oldowan-type tools referred to the stage where early humans worked hard to meet-up to their environmental demands. They searched for food, they stored and preserved food, they hunted for animals, and they had to migrate from one place to another due to climatological changes. The name Oldowan is associated with the Olduvai Gorge in Tanzania where Stone Age tools were found (Omolewa, 2008, p. 15). The various Stone Age tools were in the form of smaller pebbles, flaked cobble sand percussive items and sometimes, they appeared in the form of large or smaller cutting tools (cf.Diez-Martin, et al, 2015, p.3).

Scholars in the fields of anthropology, archaeology and paleontology have come to a point of agreement according to which Oldowan type- tools are less complicated and organized than those of the Acheulean industry termed to be more advance or said to be produced by more advance humans. Fernando Diez-Martin and others have argued that the Acheulean industry indicates the use of Stone Age tools manufactured by more advance humans than those produced and used by the humans considered to be of Oldowan type:

In regions were both technologies co-exist, it has been argued that Acheulean assemblages exhibit a higher degree of planning and curation than Oldowan assemblages. Recently, it has been shown that making Acheulean tools require more complex neurophysiological skills than Oldowan tools (Diez-Martin, et al., 2015, p.3).

The above reason made it possible to conclude that the Acheulean marked one of the most important stages in the economic, spatial, technological and cognitive adaptations of human evolution. It is a stage that can be classified, in which the early human thinking-capacity advanced and resulted in the manipulations of his/her hands in diverse ways distinctively (Torre, 2016, p. 1). More so, the Acheulean can also be classified as one of the most important stages in the transitions of human evolution. It provides us with background knowledge for the understanding of the early human techno-complexities and the historiographical context that changed the entire human history. Ignacio Torre said that "the Acheulean is the longest-lasting technology in prehistory" that altered previous scientific and religious views (Torre, 2016, pp.1-2). (Note 4)

It is also important to note that it is not only the Stone Age tools that were found in Africa that supported the possible existence of early humans, the skeleton or some parts of human bones added to the knowledge that early humans existed during the Acheulean periods. A team of researchers led by Sileshi Semaw of the Centro Nacional 
de Investigacionsobre La Evolucion Humana (CENIEH) from Spain and Michael Rogers of the Southern Connecticut State University from the USA found two craniums in the Gona area of Ethiopia. Gona is located in the Afar State and adjacent to the popularly known Middle Awash where the skeleton of Ardi was found and Hadar areas where the skeleton Lucy was found. One of the craniums was nearly complete and is estimated at about 1.5 million years while the other is a partial cranium of an early human ancestor estimated at about 1.26 million years. Both crania have been linked to both the simple Oldowan-type and a more complex Acheulean assemblage (Erickson, 2020, pp. 1-2). (Note 5)Around 1972, Richard Leakey also found the skull of a Homo rudulfensis in northern Kenya. They are said to have a small skull with a brain capacity of 750 cubic centimeters (Raven \& Johnson, 1999, p. 454). Therefore, before the emergence of the Acheulean, there were other early humans that manufactured and used tools called the Oldowan industry mostly dated to the periods between 1.5 and 1.4 million years ago (Ladan, 2016, p. 6).

\subsection{The Historical Nomenclature of the Acheulean}

The first conception of the word Acheulean is in connection with a specific location in Europe and particularly Acheul in France. Handaxes were found at a site of St. Acheul on the Somme River (northwest) in France and the handaxes were identified and classified by scholars as prehistoric tools (Sharon \& Barsky, 2015, p. 1). Torre further explained that Gabriel de Mortillet who previously considered the handaxes as the earliest Stone Age tools ever found made the findings in Acheul. He compared the features of the tools with the Paleolithic cultures and preferred to name the tools after Acheul (Omolewa, 2008, p. 8). (Note 6) The tools found in Acheul were mostly handaxes and cleavers (Ladan, 2016, p. 6).

The name or nomenclature of the Acheul tools found in France had undergone through various debates because similar kinds of tools though with distinctive features were also found in other parts of the world (Kenya, Ethiopia and South Africa)(Note 7) after the one found in France (Erickson, 2020, pp. 1-4). About ten years after his findings, de Mortillet suggested the name "Chellean" to be used to describe the Acheulaen industry he found in Acheul. Many did not welcome the idea. Breuil for example preferred the name Abbevillian and not Acheulean or Chellean and this is so because Boucher de Perthes also found for the first time some handaxes in Abbeville, northwest of France (Breuil, 1932, pp. 125-190).Another individual Astley John Hilary Goodwin also compared and divided handaxes into Earlier, Middle and Later Stone Age but he refused to use the terms Acheulean or Chellean to refer to the Stone Age tools. Instead, he used the terms "the Stellenbosch Industry" with respect to the Early Stone Age tools found at Bosman Crossing in Stellenbosch, South Africa (Goodwin, 1935, pp. 291-417). The debate on the preferred name to be used globally for identifying the Acheulean handaxes and cleavers continued throughout the twentieth century.

During the conference of the Pan-African Congress on Prehistory (Archeology) in Kenya within the periods January 11 - February 1, 1947, certain terms were agreed to be used to describe the Paleolithic industry: Chelles - Acheulean for assemblages of handaxes associated with Pithecanthropus while pre-Chelle-Acheul for Oldowan and Kafuan(Note 8) associated with Australopithecus. These nomenclatures continued to be used by African scholars and others throughout the 1950s (Torre, 2016, pp. 3-4). After the 1950s, the debates on the ages of the Oldowai items found in different layers and those of the Acheulean found in different parts of the world including Europe, Africa, the Near East and Asia made scholars to have a specific name or term to associate the early, middle and later stone age tools. They might have preferred the Acheulean (Torre, 2016, pp. 4-5). In the twenty-first century, the name Acheulean prevailed in describing handaxes and cleavers associated with the most sophisticated tools used by mostly Homo erectus and or Homo ergaster (cf. Ladan, 2016, p. 4). Torre said that of recent, the debates on the terminological descriptions of the Acheulean are not popular among scholars unlike in the nineteenth and twentieth century's (Torre, 2016, p. 2).

\subsection{The Features of the Acheulean}

The Acheulean found in different parts of the world all have distinctive features but centered all at the amygdaloidal and hand-held tools used as weapons, handaxes, biface and large cutting tool (LCT). It is likely that there is no universality on the specific features of the Acheulean rather; the items may differ according to the environment they are found. I do not believe that we should force a particular feature or features to all Acheulean artefacts found in different parts of the world instead let each artefact be studied accordingly. However, based on the Acheulean artefacts found, certain general features might be identified.

A typical and generic term for the Acheulean items is probably bifacial which include forms such as picks, knives, cleavers and bifacial handaxes but the most generic term for the Acheulean in the twenty-first century is handaxes (Torre, 2016, p.2). More so, handaxes and cleavers are the general terms used in describing the features of the Acheulean. The Acheulean handaxes could be pear shape, teadrop shape or rounded in outline and biconvex in 
cross section of about $12-20 \mathrm{~cm}$ long flake, sometime a more pointed end may extend around all parts or the greater part of periphery of the handaxes (Ladan, 2016, p. 6).With regard to the features of the Acheulean, not all of them are the same. Some of the Stone Age tools differ on the basis of stone-type and the type of shape the tools are featured. The reason for the difference has been attributed to weather and functionality. Torre explained:

....as handaxe-free assemblages from both Africa (e.g. Hope Fountain industry) and Europe (e.g. Clactonian) are likely to belong to the same techno complex as geographically and chronologically similar handaxe-bearing assemblages, in which variability is better explained by ecological and/or functional differences within a single technological tradition (Torre, 2016, p. 2).

There are certain parameters usually identified in characterizing the features of the Acheulean. A general characteristic-feature of the Acheulean which I find relevant for this research is summarized by Professor John Gowlett, one of the Directors of the British Academy Centenary Project 'Lucy to Language' and a former Senior Archeologist to the Oxford Radiocarbon Accelerator Project from 1980 to 1987. He explained that the major features of the Acheulean include:

1. a globe butt, which means a centered mass area that can be held with the human hand (see FA1 in Figure A(FA);

2. a forward extension, which suggests that a portion of the tool should provide support for the working edges of the tool;

3. thickness adjustment, which allows the mass of the tool to be reduced without altering other major morphological features of the tool and finally;

4. there should be a lateral extension around a major plane of the tool likewise the thickness adjustment between one surface of the tool and its opposite or adjacent sides (Gowlett, 2006, pp. 7-20; cf. see also Figure A(FA) from FA1 - FA8).

The Acheulean tools were likely efficient to the early humans in handling most of their physical needs. The tools were used for activities like digging, cutting, grinding and hunting fauna and many more. The cleavers and handaxes might have been used for butchering and the scrapers for producing hides for clothing or for tents making or for making wooden materials meant for domestic use. Ladan said that there is a speculation that the makers of Acheulean were the first to make human settlement or shelter and to use controlled fire (Ladan, 2016, p. 9).The sites for the Early Acheulean with respect to both bone and stones tools in Africa are all located in East Africa except the ones found in Sterkfontein and Reitputs in South Africa (Torre, 2016, p. 5). The study of the existence of early humans in West Africa and especially NAFOK is based on the availability of Stone Age tools and not tools made of bones and woods.

\section{The Acheulean Industry in NAFOK}

Mining activities on the Jos-Plateau region located in Northern or North-Central Nigeria started around the late eighteenth century. While there were recognized or registered miners, there were also people that mined randomly without formal government accreditations. Around the early and mid-twentieth century, the population of migrants from various parts of Nigeria and other countries especially the Europeans increased on the Jos-Plateau due to the attraction from mining activities. Between the periods 1900 to 1914, some of the following mining companies were registered and accredited by the government of the non-amalgamated Nigeria to conduct mining work on the Jos-Plateau: Kwall Tin Field Limited, Ropp Tin Limited, Rayfield Nigeria Limited, Niger Company Limited, Forum River Tin Company Limited and many more. Some important areas were mining activities were paramount included Ex-Lands/Gidin Akwati now called Nekan, Ropp, Bisichi, Tenti, NAFOK (Mai Idon Toro) and many more (Maren, Roseline and Adbulmalik, 2015, pp. 1414-1416).

The activities of miners had exposed the visibility and availability of some of the alleged Acheulean sites on the Jos-Plateau region and particularly Pingell and NAFOK (Mai Idon Toro) (Soper, 1965, p. 175). It is not clearly known when and who precisely started collecting Acheulean artefacts in NAFOK. In 1963, Thurstan Shaw reported that it was generally known that there were Acheulean artefacts found on the Jos-Plateau region of Pingell and NAFOK (Mai Idon Toro). He said "[i]n Nigeria, until recently this period was represented almost entirely from the Jos Plateau, where fine Acheulean tools have been known for sometimes" (Shaw, 1963, p. 451).(Note 9) Mr. Shaw said that there was a specific archeologist by the names Robert Soper then employed by the Nigerian Federal Department of Antiquities, who found some Acheulean materials in the Upper Sokoto Valley (Northern Nigeria) and that the materials found in Sokoto though Acheulean, yet have some unspecified differences with 
those found in NAFOK (Mai Idon Toro).The fact that Mr. Shaw said that archaeologists have to wait for the findings made by Robert Soper regarding the NAFOK (Mai Idon Toro) Acheulean suggest that Shaw was not the first person to work on the NAFOK Acheulean. Shaw said "Mr. Robert Soper is at present making a detailed analysis of these industries [Acheulean industries in NAFOK \& Pingell, own emphasis](Note 10)and we very much look forward to seeing the results of his studies" (Shaw, 1963, p. 451).

The presentation of Robert Soper was mainly due to the fieldwork he carried out sometime between 1962 and 1964. Around 1965, it was assumed that Robert Soper might have completed his research work on the Jos-Plateau Acheulean.In his paper, Soper reported that an individual by the name Braunholtz was the first person in 1926 to publish about the availability of handaxes, Middle Stone Age flakes; polish axes and the alluvial deposits on the exposed mines of NAFOK (Mai Idon Toro).(Note 11)Soper said that after Braunholtz, Balfour could have likely been the next person to report about cleavers found in NAFOK in 1934.(Note 12) Soper further noted that other important personalities that conducted a scientific study of Acheulean found in NAFOK (Mai Idon Toro) are Bernard Buller Fagg and Bond: "... the only general scientific description of the Stone Age industries and Pleistocene stratigraphy of the area [NAFOK (Mai Idon Toro) - were done by Fagg and Bond, own emphasis]" (Soper, 1965, p. 175).(Note 13)Soper said that from 1947 through 1948, about 2500 artefacts including cleavers and handaxes were collected from NAFOK (Mai Idon Toro) and carefully studied and observed by H.F. Burton, an ardent protector of the British monuments (Soper, 1965, p. 179).

In the search for primary sources in order to obtain information on the first study of the Acheulean at NAFOK, I contacted the archeologist Robert Soper who was glad to interact with me. Unfortunately, he said he is too old at present and cannot remember so much about the archaeological works he did around Jos-Plateau region; instead, he referred me to read through his publications on the subject. He said:

Dear Agai Jock, Yes, I was in northern Nigeria in [the] 60s as my first dig. I will be happy for you to quote my work, which I do not remember now. All the best, Robert Soper. (Note 14)

He further noted that the works he did in Northern Nigeria pertained to Stone Age tools but his interest seemed to be more about his works in East Africa that pertained to Iron Age tools and not Stone Age tools. He said:

Dear Agai Jock, I am sorry that I do not remember much data now that I am 82 , though I remember rather vaguely the places I went to! Also when I left Nigeria for East Africa I worked on Iron Age rather than Stone Age. Presumably you can see my published items of the early 1960s? Best wishes, Robert Soper.(Note 15)

Therefore, Thurstan Shaw earnestly waited to hear from Robert Soper about his study of the artefacts found in NAFOK. Robert Soper went to NAFOK, collected and studied artefacts. He also relied on the views of other archeologists like Braunholtz and Balfour in order for him to interpret the artefacts. The extent or status of contribution Robert Soper made to the NAFOK Acheulean may not be clearly determined at this stage. Soper presented some photos of many Stone Age tools found in the Jos- Plateau region (Soper, 1965, pp. 175-180). He also showed the stone tools that were found in NAFOK (Figure A1).The fact that Soper said some of the stone tools he studied are kept at the National Museum in Jos suggest that the Acheulean in NAFOK might have been studied from a professional point of view (Soper, 1965, p. 179).

Later around 2004, in one of Thurstan Shaw's articles, he reported that many more cleavers were found in NAFOK non-comparable in number to those found in any parts of Nigeria. He said the cleavers found at NAFOK might have been used around 65, $000 \mathrm{BCE}$. He noted that the Jos-Plateau region might have experienced the Pleistocene epoch (Shaw, 2004, pp. 26-27).(Note 16) Just as Thurstan Shaw had already reported, Ladan echoed a similar sentiment by noting that there were Acheulean found in NAFOK (Mai Idon Toro) and the cleavers were numerous and outnumbered the handaxes. Ladan said that about 692 Acheulean tools were found in NAFOK (Mai Idon Toro) most of which were made of fine granite and a few chalcedony (Ladan, 2016, p. 11). 


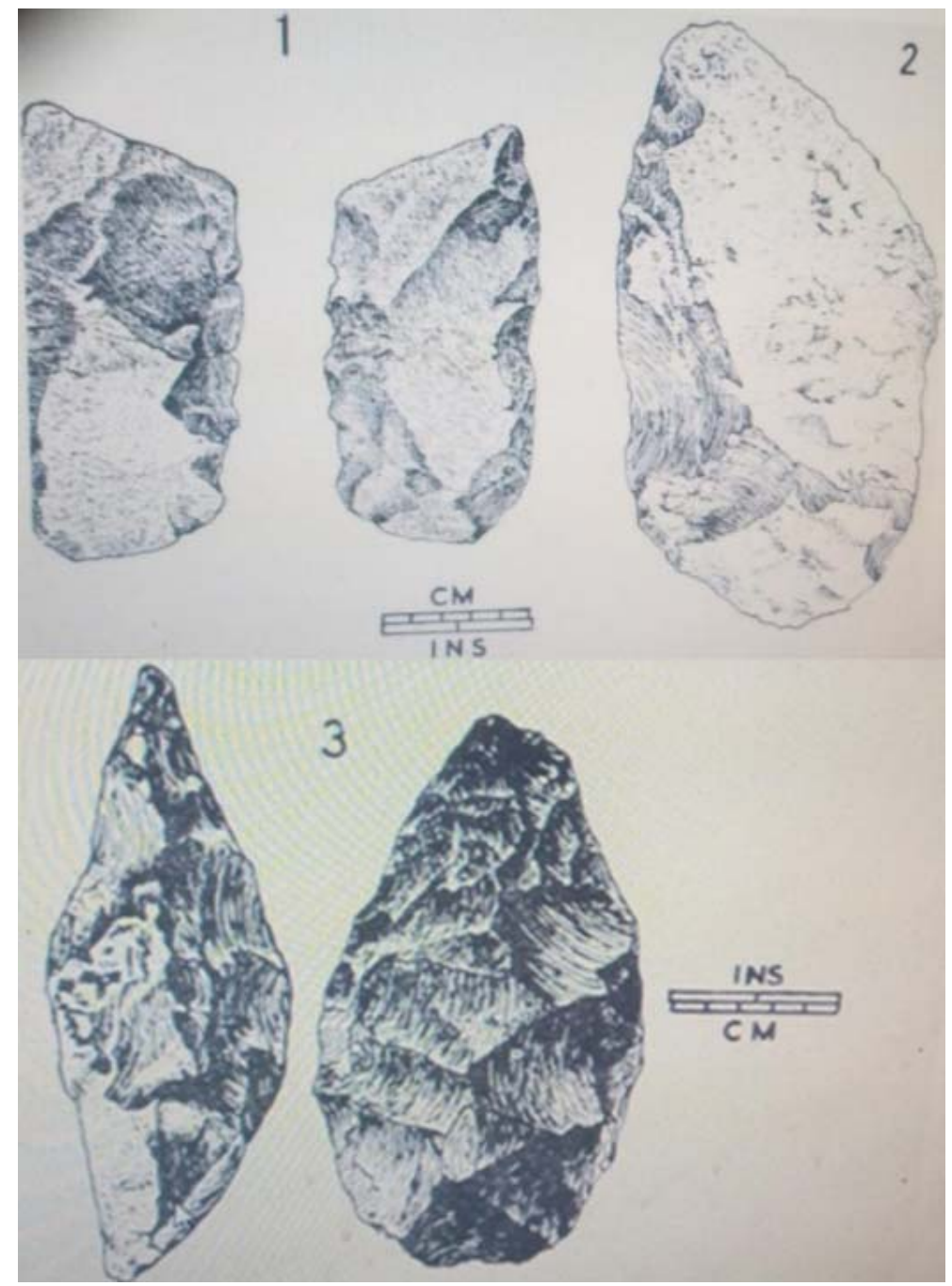

Figure A1. This is a photo of the Acheulean tools found at Mai ldon Toro (NAFOK) and presented by Robert Soper. He said that No. 1 is an oblique edged cleaver of basalt and the photo taken from two different directions. No. 2 is an oblique edged cleaver of granite and No. 3 is a handaxe made of chalcedony, from "The Stone Age in Northern Nigeria," Journal of the Historicol Society of Nigerla, 3(2), p.186

Furthermore, Dr. Jock who is a research associate in the School of Religion, Philosophy and Classics, Faculty of Humanities, University of KwaZulu-Natal where he obtained his $\mathrm{PhD}$ in historical Studies led the team of researchers that visited NAFOK in 2020. He was a former research assistant in the Department of Ancient Near Eastern Studies, University of South Africa. He participated in many archaeological and archaezoological trainings, workshops and conferences. The team found twenty artefacts most of which are stone tools. Other items found are pottery, bones and well-carved flake cleavers with bifacial and unificial features in small and large sizes (Figure A (FA)).

In addition, the team obtained the items on the previously mining sites about 100 meters away from the NAFOK River and on the surfaces of the dug soil without any archaeological excavation. Some of the items are shown in figure A (FA). Figures FA1, FA2, FA3 are the same basalt stone tool viewed from different directions. The item might have been used for hunting, for self-defense and for breaking food items such as bones and coconuts (that is if coconuts are among the fruits that existed millions of years ago) likewise for digging. The posterior of the tool can be held tightly and comfortably with one hand or two hands all together while exerting a great pressure to force a colliding or an opposing item to be broken or destroyed. This can be achieved by forcing the lateralhemispheric and semi-sharp-edge portion of the tool. The tool corresponds in features with those described by Professor John Gowlett (see 3.3 cf. Gowlett, 2006, pp. 7-20). 

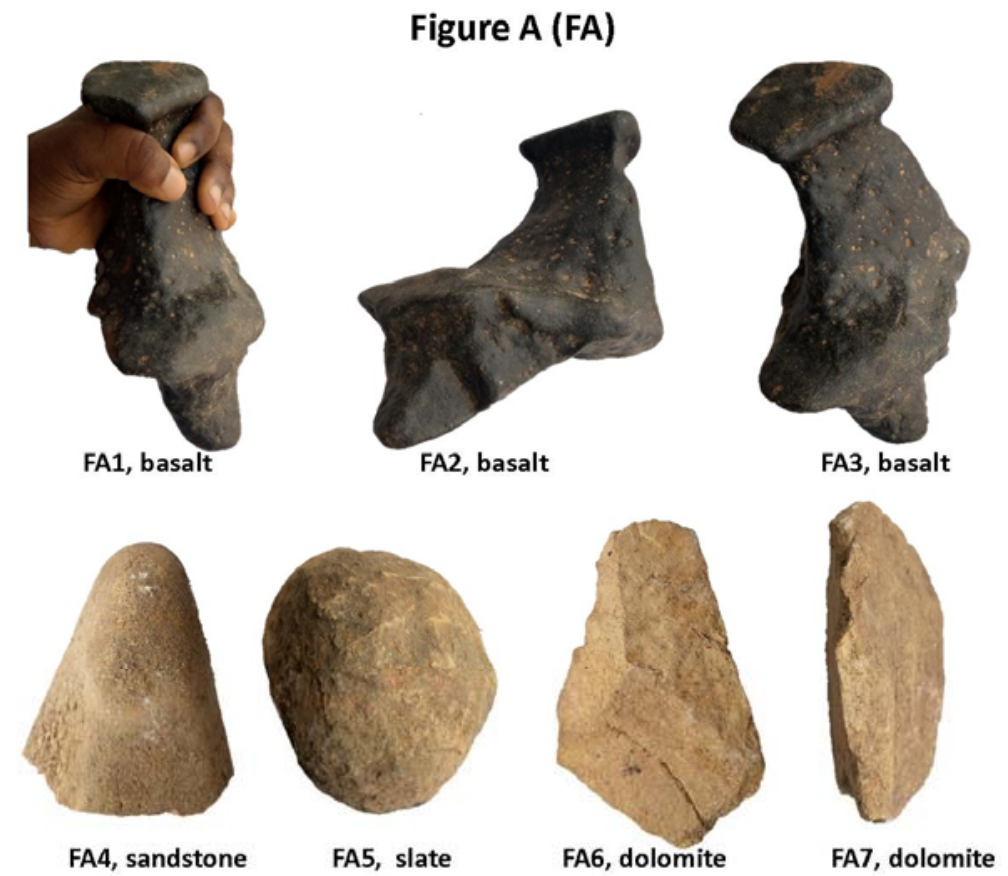

FA4, sandstone FA5, slate FA6, dolomite

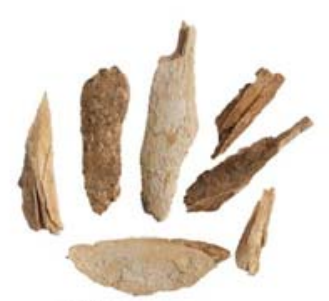

FA9, bones

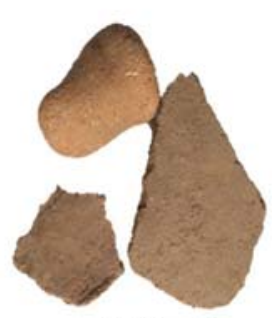

FA10, pottery

Figure FA4 is half-broken spherically shaped sandstone that might have been used for grinding foodstuff or for sharpening wood and other stone tools. It might have been used also for mashing up leaves or seeds into power or smaller forms. It is likely that the rounded and smoothly edged anterior was used inside a stone bowl (mortar) as a pestle while the flat posterior used for grinding on another smooth flat surface. Figure FA5 is a round slate metamorphic rock of a shot-put size that might have been used as artillery or a weapon for attack. The surface, though carefully carved is not as smooth as the surfaces that were likely used for grinding. Figure FA6 is a nonmineral dolomite that is unifacial. It is carefully carved and might have been used for cutting while Figure FA7 is also a dolomite that is bifacial and might have been used for cutting as well. Figure FA8 is a dolomite stone tool that might have been used for cutting, piercing, scrapping and or for chopping. Figures FA8 and FA10 are bones and pottery the team found in NAFOK. The discussion about Figures FA9 and FA10 are beyond the scope of this research because the research focuses strictly on Stone Age tools.

Several archaeologists, historians and curators from the 1920s to the 1960s like Hermann Justus Braunholtz, Henry Balfour, Benard Fagg, Robert Soper, Thurstan Shaw and others have studied and analyzed the alleged Acheulean tools found at NAFOK. Although it cannot be proven clearly the methodology they applied in their study of the items, they all seemed to reach a conclusion that there existed the Acheulean industry in NAFOK (Mai Idon Toro). They thought that the cleavers and handaxes found at NAFOK could be comparable to those found in East Africa by Leakey and others. In other words, a number of scholars have opinioned that Jos-Plateau had experienced the Pleistocene epoch. Thurstan Shaw said:

In Nigeria until recently this period was represented almost entirely from the Jos Plateau, where five Acheulean tools have been known for sometime, and where geological circumstances of their occurrence have been studied. It was the view expressed in one of these studies that this material belong to the later 
stages of hand-axe culture and was 'typologically equivalent to Leakey's Acheul Stages Four and Five in East Africa, and to Stellenbosch three or four in the Vaal river sequence of South Africa (Shaw, 1963, p. 451).

The Pleistocene is a drastic climatic period that changed the surfaces of many parts of the world and led to the migration of early humans and animals from one place to another. It started about 1.8 million to 11,000 years ago unlike the Holocene that only started from 11, 000 years ago to present (Ladan, 2016, pp. 3-4). Robert Soper said that both Bernard Fagg and Geoffrey Bond believed that certain parts of the Jos Plateau experienced the Pleistocene. He said "Fagg and Bond ... have since given the only general scientific description of the Stone Age industries and Pleistocene stratigraphy of the area [Jos Plateau including NAFOK, own emphasis]" (Soper, 1965, p. 175). Shaw further noted that Jos Plateau weather; climate and landscape could have been accommodative for Acheulean humans (Shaw, 2004, p. 26). He thought that the Acheulean humans that inhibited Nigeria and Jos Plateau in particular might have been originated from East Africa or were likely colonized by the Sangoan culture from East Africa (Shaw, 1963, p. 452).

No professional archaeological excavation has been done in NAFOK up-to-date. Previous mining activities in the early and mid-90s exposed many Stone Age tools that are easily and readily accessible. Some of the items found by Dr. Agai Jock and his team of researchers in NAFOK is closely related and functionally comparable to the ones presented by Robert Soper (Figure A1). The tools found in NAFOK are flake cleavers and handaxes type in bifacial and unifacial shapes. The stone especially Figures A (FA): FA1, FA2 and FA3 seemed to be carefully trimmed to meet the purpose for which it was meant. The manner in which the stone tools were carefully made suggests that advanced or large brain-size humans might have used them likely of the Late Stone Age.(Note 17)Based on the physical evaluation and analysis of the stone tools found in NAFOK, it can be suggested that they were made and used by the last or the Late Stone Age Homo erectus.(Note 18)There is no any absolute result about the age or ages of the alleged Stone Age tools found by Dr. Agai Jock and his team.

\section{Conclusion and Recommendation}

The handaxes and cleavers found in NAFOK can be classified or identified as Late Stone Age tools and are comparable or similar in form and function to the Acheulean industry found in Kenya and in Ethiopia. This view is necessitated by previous archaeological study and analysis of Stone Age tools found in NAFOK by other archaeologists before the twenty-first century. Dr. Agai Jock Matthew and his team of researchers also found that the alleged Late Stone Age tools in NAFOK reveal similar features as those explained and statute by previous archaeologists who worked on the Mai Idon Toro (NAFOK) Acheulean from the 1920s to the 1960s. This research reveals that there was an Acheulean industry in NAFOK that might have been developed and used by Late Stone Age Homo erectus.(Note 19)This hypothesis is not based on scientific calibrations that used archeological equipment that measures the age of the artefacts, instead the hypothesis is based on previous works done by other archeologists and also based on the physical analysis of the Stone Age tools found by Dr. Agai Jock and his team of researchers. The tools he found are now kept at the NAFOK community library for further research.

It is pertinent to note that that there is at present no archaeological excavation ever conducted in NAFOK and there seem to be little or no clearer evidence that thorough, chronological and progressive scientific study of the Acheulean industry in NAFOK has ever been done. The people of NAFOK earnestly hoped that archeologists in Nigeria or outside of Nigeria should come to excavate the mining area in NAFOK where the stone tools are found. The elites and the educated people of NAFOK are of the view that more reliable items and evidence for the Acheulean in NAFOK can be found if excavation is conducted. Seemed the Federal Government of Nigeria through the National Commission for Museums and Monuments have indicated their intention to classify NAFOK (Mai Idon Toro) as a National Monument in 2013 (see Appendix A), it will be a plus to public archaeology if the intention is implemented by first, preserving the specific area and second, by supporting institutions or persons that are willing to conduct archaeological researches in the area. If the Acheulean side in NAFOK is made a National Monument or a heritage site, it will attract other researchers and the general public at large for site views and for students' excursions.

Acknowledgements: I wish to appreciate the supreme Chief/Gwom NAFOK Da Gyang Wang Pam and his seven ward heads for the good way they accommodated our research team in NAFOK. The seven ward heads and other community leaders in NAFOK served as our tour guides. The supreme chief permitted our team of researchers to obtain any artefact needed for further study. I also appreciate Robert Soper and the staffers of the National Museum in Jos for their professional advices on the success of this research.

Competing Interest: The author declares that there is no competing interest. 
Compliance with Ethical Standards: The article complied with all ethical standards without any intention to hurt any group or their belief systems.

Author's Contributions: This article was written by Jock Matthew Agai.

Data Availability Statement: Data sharing is not applicable to this article as no new data were created or analyzed in this study.

Disclaimer: The views expressed in this article are those of the author.

\section{References}

Agai, M. J. (2014). An Archaeological Search for the Emergence of Early Humans in West Africa. HTS Teolologiese Studies/Theological Studies, 70(1), 1-7. Art.\#2033. https://doi.org/10.4102/hts.v70i1.2033

Agai, M. J., Danjuma, P., Chiwem, C. D., \& Dido, G. E. (2020). Field Work in Search of Stone Age tools at Mai Idon Toro (NAFOK), $31^{\text {st } M a y . ~}$

Balfour, H. (1934). Occurrence of Cleavers of Lower Palaeolithic Type in Northern Nigeria. MAN, 1-25, 1934.

Boateng, A. E. (1978). A Political Geography of Africa (University of Cambridge Press, London, 1978).

Bond, G. (1956).A preliminary Account of the Pleistocene Geology of the Plateau Tin Fields Region of Northern Nigeria.Proceedings of the International West Africa Conference 1949, Ibadan, 187-202, 1956.

Braunholtz, J. H. (1926). Stone Implements of Palaeolithic and Neolithic Type from Nigeria. Occasional Paper No. 4, Geological Survey of Nigeria, 124-184.

Breuil, H. (1932). LesIndustrisa Eclats du Paleolithique Acien, 1. -Le Clantonien. Prehistoir 1.

Chan, S. (1997). Man and Sin: An Independent Study Textbook, $2^{\text {nd }}$ (edition), ICI University Press, Texas.

Diez-Martin, F. (2015). The Origin of the Acheulean: The 1.7 Million-Year-Old Site of FLK West, Oldovai Gorge (Tanzania). Retrieved from http://www.nature.com/articles/sren17839

Erickson, J. (2020). Smallest Homo Erectus Cranium in Africa and Diverse Stone Tools Found at Gona, Ethiopia. Retrieved 13/7/2020 from http://phys.org/news/2020-03-smallest-homo-erectus-cranium-africa.html

Fagg B.E.B. (1956). An Outline of the Stone Age of the Plateau Minesfield.Proceeding of the International West African Conference1949, Ibadan, 1-20.

Gore, R. (2003). The Rise of Mammal. National Geographic, 203(4), 2-37, 2003.

Goodwin, A. J. H. (1935). A Commentary on the History and Present Position of South African Prehistory with Full Bibliography. Bantu Stud., (9), 291-417. Retrieved from http://europepmc.org/articles/PMC4920301/

Gowlett J. A. J. (2006). The Elements of Design form in AcheulianBifaces: Modes, Modalities, Rules and Language. Axe Age Acheulian Tool Making from Quarry to Discard, Goren-Inbar N. and Sharon G. (edited), London, Equinox, 1-20. Retrieved 2/8/2019 from http://pcwww.liv.ac.uk/ gowlett/gowlett-designform-jer1005.pdf

Green, O. P., Stout, G. W., \& John, D. T. (1990). Biological science 2: Systems, Maintenance and Change, Soper R. (edited), (Cambridge University Press, New York, 1990).

Harvati, K., Chris, S., Rainer, G., Maxime, A. (2011). Philip Allsworth-Jones and Caleb Adebayo Folorunso, “The Later Stone Age from Iwo Eleru, Nigeria: Morphology and Chronology. PLOS ONE, 6(9), 1-16. https://doi.org/10371/journal.pnone.0024024

Ladan, N. P. (2016). Examining the Basic Attributes of the Acheulian Industries: A Case Study of West Africa," Ahmadu Bello University Zaria, 1-27. Retrieved 3/5/2020 from http://www.google.com/url?sa=t\&source=web\&rct=j\&url=https://www.academia.edu/3025244/EXAMINI NG_THE_ACHEULIAN_ATTRIBUTES_A_CASE_STUDY_OF_WEST_AFRICA\&ved=2ahUKEwiTS8s $1-$

e3qAhWMzoUKHTfRDewQFjAAegQIAxAC\&usg=AOvVaw2clfriOEAblcJSExndjJO\&cshid=159587061 1641

Lange, D. (2004). Ancient Kingdoms of West Africa: Africa-Centred and Canaanite-Israelites Perspective, a Collection of Published and Unpublished Studies in English and French (J.H. Roll, Dettelbach, 2004).

Maren, A. B., Roseline, O. M., \& Abdulmalik, S. (2015). Immigrant Populations Growth, Trade Opportunities and Inter-Group Relations in Jos Mining Camps 1914-1945. Valley International Journal, 2(6), 1415-1423. Retrieved 7/8/2020 from http://valleyinternational.net/index.php/our-jou/thesjsshi 
Omolewa, M. (2008). Certificate history of Nigeria (Longman, Ikeja, 2008).

Pam, G. B. (2020). Interview on "The Acheulean in NAFOK," $31^{\text {st }}$ May 2020.

Paul, B. H. (1994). Genesis: An Independent-Study Textbook (ICI University Press, Irving, 1994).

Raven, H. P., \& Johnson, B. G. (1999). Biology $5^{\text {th }}$ (edition)(WCB McGraw-Hill, New York, 1999).

Scheepers, C., \& Scheffler, E. (2000). From Dan to Beersheba: An Archaeological Tour of Ancient Israel (Biblia, Pretoria,2000).

Shaw, Thurstan: English Archaeologist (1914-2013). Biography, Facts, Career, 1-4. Retrieved 19/7/2020 from https://peoplepill.com/people/charles-thurstan-shaw/

Shaw, T. (2004). Prehistory.Groundwork of Nigerian history, O. Ikime (edited) (Heinemann Educational Books, Jos, 25-53.

Shaw, T. (1963). Field Research in Nigerian Archaeology: A Brief Survey and Discussion of Policy. Journal of Historical Society of Nigeria, 2(4), 449-464.

Shaw, T. (1978). Nigeria: Its Archeology and Early History (Thames and Hudson Inc., New York, 1978).

Sharon, G., \& Barsky, R. D. (2015). The Emergence of the Acheulian in Europe - A Look from the East. Quaternary International, 1-9. https://doi.org/10.1016/j.quaint.2015.11.108

Soper, C. R. (1965). The Stone Age in Northern Nigeria.Journal of Historical Society of Nigeria, 3(2), 175-194.

Soper, C. Robert, Interview with Robert Soper on "The Acheulean on the Jos-Plateau," via https://www.academia.edu/Messages, $2^{\text {nd }}$ and $5^{\text {th }}$ August 2020.

Torre, I. (2016). The Origins of the Acheulean: Past and Present Perspectives on a Major Transition in Human Evolution. Philosophical Transactions, 1-34. https://doi.org/10.1098/rstb.2015.0245

Welch, A. C. (1963). Biological Science: Molecules to Man (Houghton Mifflin Company, Boston, 1963).

Wesler, W. K. (2002). Historical Archeology in West Africa. Studies in the History of Central Nigeria Area, 1, 139, (Church Society and Suppliers, Lagos, 2002).

\section{Notes}

Note 1. Agai, J. M., Danjuma, P., Chiwem, C. D., \& Dido, E. G., 2020, Field Work in Search of Stone Age tools at Mai Idon Toro, $31^{\text {st }}$ May.

Note 2. NAFOK in Berom-Foron dialect means, "I heard you." The historical context that led to the use of the phrase "I heard you" is ongoing. The indigenes of NAFOK said that they could only remember that their ancestors told them that NAFOK is the original name of the location some people now call Mai Idon Toro.

Note 3. Agai, J. M., Danjuma, P., Chiwem, C. D., \& Dido, E. G., 2020, Field Work in Search of Stone Age tools at Mai Idon Toro, $31^{\text {st }}$ May.

Note 4. The Acheulean altered some conservative biblical views. Some evangelical Christians use to think that the Age of the earth can be determined after the Flood described in Genesis 7 and 8 (Paul, 1994, p. 29). Archbishop James Ussher (1581 - 1656) studied the chronology of the genealogies in Genesis 1 and came to the conclusion that the earth was created in 4004 BCE thus estimating that the earth might have been created between 6000 and 7000 years ago (Chan, 1997, p. 43). In fact, Green, Stout and Taylor said that the radioactive method of dating rocks (geochronology) indicates that the earth is about five billion years old (Green, Stout and Taylor, 1990, pp. 861-862). The Acheulean has changed the history of the age of the earth pointing out that humans live long before the Flood and that the earth is billions of years old inhibited by early humans millions of years ago (cf. Torre, 2016, p.. 1-2).

Note 5. Other Stone Age tools that were found in Gona are picks, cleavers and the crudely developed bifaces on both flakes and cobbles (Torre, 2016, p.110).

Note 6. The Paleolithic period meant the Old Stone Age where humans started to use chipped stone tools. The period might have begun about 2.5 to 2 million years ago. The period could further be divided into Lower Paleolithic (1,000 000 BCE- 120,000 BCE), Middle Paleolithic (120, 000 BCE - 45, 000 BCE) and Upper Paleolithic (45, 000 BCE - 18, 000 BCE) (Scheepers \& Scheffler, 2000, blurb).

Note 7. While the study of handaxes in Acheul was ongoing, similar kinds of researches were equally done around some parts of Africa. The Acheulean found in Africa are said to be older than the ones found in Europe. Torre said 
that the Acheulean found in East Africa are about 1.4 to 1.5 million years old while the one in Europe is about 1 million years old (Torre 2016, 5). Diez-Martin also said that the oldest form of the Acheulean evidence or form of technology dates back to 1.7 million years and is limited toKokiselei [Kenya] and Konso [Ethiopia], both of which lacked functionality-associated fauna (Diez-Martin, et al., 2016, p. 4).

Note 8. The Kafuan is consisting of earlier found pebbles and flake industries in Uganda also called KafuanVillafranchian which corresponds to the first Pluvial, Kagerran.

Note 9. Charles Thurstan Shaw, the English archaeologist was born on 27 June 1914 in Plymouth, England. He had great academic interest on the ancient cultures of Ghana and Nigeria and as a result, he contributed to the establishment of the Ghana National Museum and he started the archaeology departments both in the University of Ghana and the University of Ibadan in Nigeria. After an assessment of many of his publications, the University of Cambridge awarded him a PhD in 1968. He was the founder and the editor of the renowned Journal of West African Archaeological Newsletter from 1964-1970. He became the editor of the West African Journal of Archaeology from 1971-1975. He is known for his prestigious excavations at Igbo-Ukwu where he found artefacts of an ancient culture of about the ninth century BCE. He retired in 1974. His archeological works or studies in Northern Nigeria including NAFOK are not much-pronounced; instead his popularity is on his contribution to the Ibgo-Ukwu excavations and the Iwo Eleru skull of an alleged Later Stone Age human (cf. Harvati, et al, 2011, p. 1-9; Agai, 2014, p. 5; “Shaw Thurstsan: English archaeologist (1914-2013) Biography, facts, career...," from https://peoplepill.com/people/charles-thurstan-shaw/).

Note 10. The archeological work at Pingell was stopped and not much about it is known or has been studied except those ofNAFOK (Mai Idon Toro) (cf. Shaw, 1963, p. 451).

Note 11. It is likely that Hermann Justus Braunholtz (1888-1963) was the first archaeologist to study the Acheulaen industry found in NAFOK (Mai Idon Toro) according to Soper. Braunholtz was born in England and was educated at Cambridge. He served as president of the Royal Anthropological Institute of Great Britain and Ireland for three different terms. He became the keeper of the ethnographical department of the British Museum from 1946 to 1953. Soper said that Braunholtz presented his works on the NAFOK Acheulean in 1926 in his paper "Stone implement of the Paleolithic and Neolithic type from Nigeria."

Note 12. Henry Balfour (11 April 1863 - 9 February 1939) was a British archaeologist who also had interest in animal morphology. He was the first curator of the prestigious Pitt River Museum founded in 1884. The Museum is now a department of the Oxford University and have over 500, 000 objects, photographs and manuscripts from all over the world. Balfour's paper where he discussed the Acheulean in NAFOK is entitled "Occurrence of cleavers of Lower Palaeolithic type in Northern Nigeria" published in 1934.

Note 13. Geoffrey Bond is a renowned archaeologist but his popularity in Jos-Plateau is not protruded as it is for Bernard Fagg (8 December 1915 - 14 August 1987) who was a British archaeologist and a Museum curator. Fagg is a founding father of the National Museum in Jos, which he founded in 1952 and helped, in appointing Kenneth Murray as the director of the museum. Murray retired in 1957 and Fagg took over as the director. He [Fagg] studied classics, archaeology and anthropology at Downing College, University of Cambridge and he served the British government in Jos from 1939. He did not conduct any archaeological excavation in NAFOK but the fact that he conducted an excavation in the Ropp rock shelter, few kilometers from NAFOK and found Early Stone Age implements suggests that his views about the Acheulean in NAFOK may be of great contribution to the subject under study. His fame was boosted after his work on the Nok culture where he studied and marketed the Nok terracotta to the world. Bernard Fagg also served as the curator of the Pitt Rivers Museum in Oxford in 1963.

Note 14. Interview with Robert Soper "The Acheuleanon the Jos-Plateau," via https://www.academia.edu/Messages, $2^{\text {nd }}$ August, 2020.

Note 15. Interview with Robert Soper "The Acheulean on the Jos-Plateau," via https://www.academia.edu/Messages, $5^{\text {th }}$ August, 2020.

Note 16. One of the community leaders in NAFOK, Mr. Bulus Gwom Pam who is also a professional builder and a lecturer at the Department of Building Technology, Plateau State Polytechnic Barkin Ladi alleged that his late Father Gwom Pam told them that Thurstan Shaw came to NAFOK for research (Interview with Bulus Gwom Pam, "The Acheulean in NAFOK," $31^{\text {st }}$ May 2020).

Note 17. Omolewa said that Nigeria took part in the Stone Age civilizations. He divided the Stone Age into three periods: Early Stone Age (3, 000, $000-35,000$ BCE), Middle Stone Age (35, $000-15,000$ BCE) and finally the Late Stone Age (15, 000 - 500 BCE) (Omolewa, 2008, p. 15). 
Note 18. There used to be a debate on whether Homo erectus developed from Homo ergaster or whether the two were contemporaries and this is so because the two developed about 1.8 million years ago and both might have used fine Acheulean tools (Ladan, 2016, p. 4). There seem to be a consensus among many archaeologists that Acheulean implements were manufactured and used by Homo erectus (Shaw, 2004, p. 26).

Note 19. Bone evidence for the existence of the Acheulean in East and Southern Africa are more relied-upon and pronounced than stone tools. This makes it possible to suggest that stone tools could be regarded as indirect evidence for the existence of the Acheulean while bone tools could be regarded as direct evidence for the existence of the Acheulean. The view according to which Homo erectus might have used the stone tools found in NAFOK is due to the presence of the indirect stone tools evidence.

\section{Appendix A}

A copy of the approval letter for the recognition of Mai ldon Toro (NAFOK)and other sites in Nigeria as National Monuments.

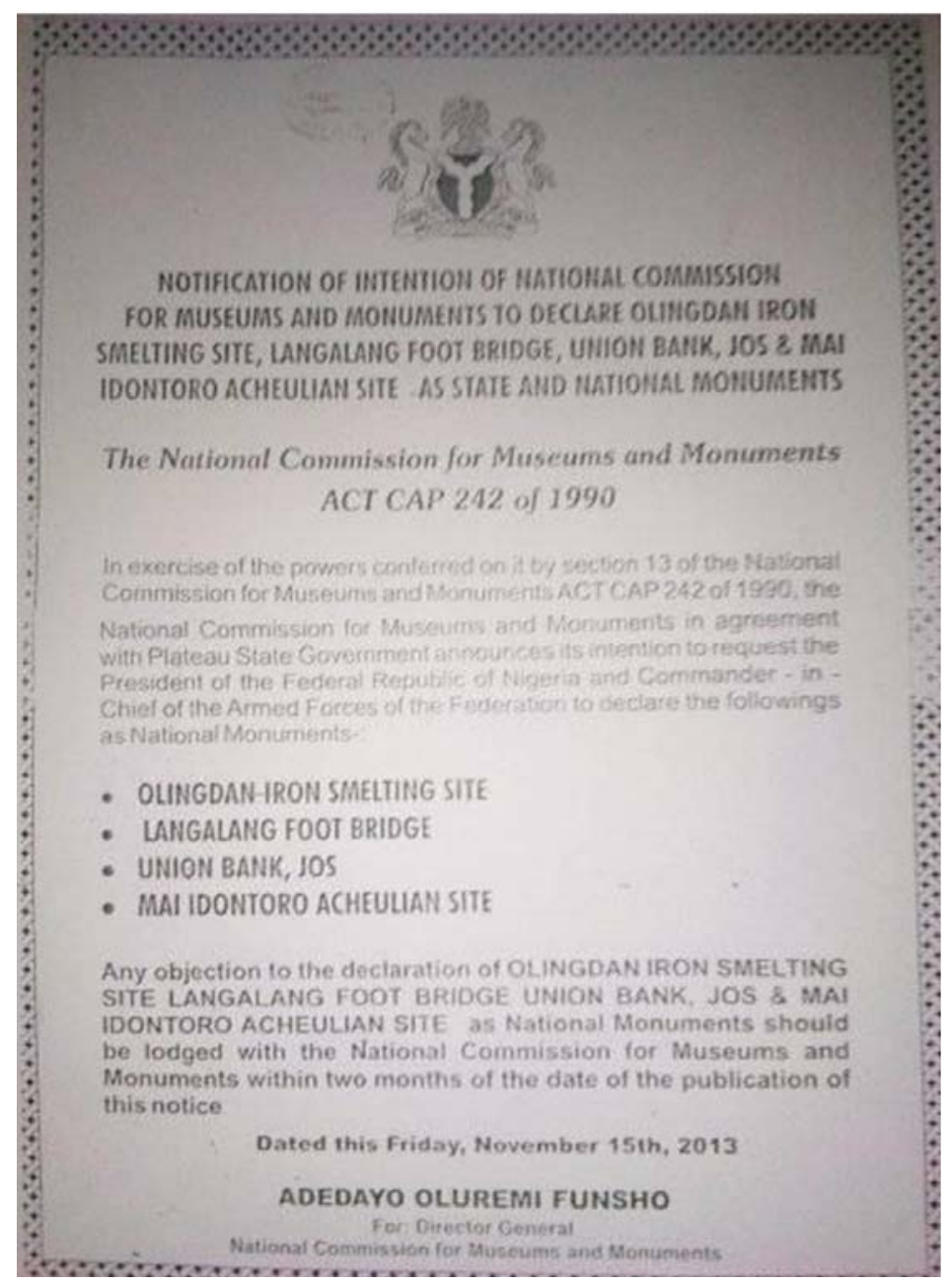

\section{Copyrights}

Copyright for this article is retained by the author(s), with first publication rights granted to the journal.

This is an open-access article distributed under the terms and conditions of the Creative Commons Attribution license (http://creativecommons.org/licenses/by/4.0/). 